Article

\title{
Antimicrobial Activity and Mechanism of Action of the Amaranthus tricolor Crude Extract against Staphylococcus aureus and Potential Application in Cooked Meat
}

\author{
Ling Guo ${ }^{1}$, Yanyan Wang ${ }^{1}$, Xue Bi ${ }^{1}$, Kai Duo ${ }^{2}$, Qi Sun ${ }^{1}$, Xueqi Yun ${ }^{1}$, Yibo Zhang ${ }^{1}$, Peng Fei ${ }^{3, *}$ \\ and Jianchun Han ${ }^{4,5}$ \\ 1 Key Lab of Dairy Science, Ministry of Education, College of Food Science, Northeast Agricultural University, \\ Harbin 150030, China; guoling@neau.edu.cn (L.G.); wyy1792830896@163.com (Y.W.); \\ xuejingupup@163.com (X.B.); 15754505440@163.com (Q.S.); vaeyxq009@163.com (X.Y.); \\ Yibo_Zhang@163.com (Y.Z.) \\ 2 Heilongjiang Institute for Food and Drug Control, Harbin 150001, China; duokai305@126.com \\ 3 College of Food and Bioengineering, Henan University of Science and Technology, Luoyang 471023, China \\ 4 College of Food Science, Northeast Agricultural University, Harbin 150030, China; \\ hanjianchun@hotmail.com \\ 5 Heilongjiang Green Food Science Research Institute, Harbin 150028, China \\ * Correspondence: feipeng0220@126.com; Tel.: +86-379-642-2342; Fax: +86-379-642-2342
}

Received: 14 February 2020; Accepted: 17 March 2020; Published: 19 March 2020

check for updates

\begin{abstract}
Amaranthus tricolor has been reported to contain some antimicrobial compounds, such as alkaloids, polyphenols, and terpenoids. However, its effect on Staphylococcus aureus has been less well researched. Therefore, this study was designed to evaluate the antimicrobial activity and possible mechanism of action of the Amaranthus tricolor crude extract (ATCE) against S. aureus and potential application in cooked meat. The antimicrobial activity against $S$. aureus was assessed by disk diffusion, minimum inhibitory concentration (MIC) determinations, and growth curve. The changes of bacterial membrane potential, intracellular $\mathrm{pH}\left(\mathrm{pH}_{\mathrm{in}}\right)$, content of bacterial protein and DNA, and cell morphology were measured to indicate its antimicrobial mechanism of action. The effects of different concentrations of ATCE on bacterial counts, $\mathrm{pH}$, and color of lean cooked pork during $6 \mathrm{~d}$ storage were assessed. The results showed that the diameter of inhibition zone (DIZ) and MIC of ATCE against $S$. aureus were $12.63 \pm 0.34$ to $12.94 \pm 0.43 \mathrm{~mm}$ and $80 \mathrm{mg} / \mathrm{mL}$, respectively. The mechanism of action of ATCE against $S$. aureus was associated with cell membrane depolarization, reduction of $\mathrm{pH}_{\mathrm{in}}$, decrease of bacterial protein content, cleavage of cell DNA, and leakage of cytoplasm. Besides, ATCE resulted in a reduction of $1.02 \log \mathrm{CFU} / \mathrm{g}$ from $3 \log \mathrm{CFU} / \mathrm{g}$ in S. aureus-inoculated lean cooked pork. The $\mathrm{pH}$ values of lean cooked pork treated with ATCE did not show significant changes as the storage time increased, but there was a slight and significant decrease seen with the application of 1 and 2 MIC of ATCE. After treating with ATCE, the color of lean cooked pork showed less lightness ( $\left.\mathrm{L}^{*}\right)$, more redness $(a *)$, similar yellowness $\left(b^{*}\right)$, stronger chroma $\left(C^{*}\right)$, and weaker hue angle $\left(h^{*}\right)$ during 6 days of storage. Therefore, these findings indicate that ATCE has antimicrobial activities against S. aureus and possesses latent energy to become a natural preservative to maintain the quality of lean cooked pork.
\end{abstract}

Keywords: Staphylococcus aureus; Amaranthus tricolor crude extract; antimicrobial activity; mechanism of action; cooked pork 


\section{Introduction}

Staphylococcus aureus is a Gram-positive bacterium belonging to the Firmicutes family, and is one of the most frequent foodborne pathogenic bacteria [1,2]. It is also one of the most significant zoonotic pathogens and has recently presented a resistance tendency in nosocomial infections [2]. It can survive in a wide range of environments, such as temperatures from 7 to $48.5^{\circ} \mathrm{C}$, pHs between 4.0 and 10.0 , and high salt concentration as well as stressful environments, and is easily spread through the air or causes contamination via contact $[3,4]$. These characteristics contribute to the growth and reproduction of $S$. aureus, and increase the contamination rate [1]. In recent years, outbreaks of foodborne diseases due to the contamination of $S$. aureus were reported often. For example, the European Union reported that 35 outbreaks led to 777 cases, and an estimated 241,000 illnesses strike Americans every year [3,4]. Consumers may be exposed to the risk of $S$. aureus contamination from the processing or manufacturing of cooked meat, dairy, eggs, beans, aquatic products, fresh vegetables, and ready-to-eat foods $[2,4,5]$. Therefore, some measures (e.g., synthetic preservatives) were taken to control S. aureus contamination to ensure food safety, but it is still a problem worthy of attention in the food industry.

A variety of synthetic preservatives (e.g., sodium benzoate and potassium sorbate) are used to inhibit the growth of bacteria in order to ensure food safety. The problem about the safety of synthetic preservatives used in food as well as the effectiveness of natural preservatives is currently in the limelight, and due to their nature and relative safety natural extracts are favored by consumers, which can hopefully be used as alternative food preservatives to inhibit the growth of pathogenic bacteria [6]. Some plant extracts, such as Thymus vulgaris, Origanum vulgare, Rosmarinus officinalis, and Cinnamon extracts, have been demonstrated to exhibit effective antimicrobial activity against S. aureus [7-9], in which the active ingredients include thymol, carvacrol, camphor, and cinnamaldehyde, respectively. On the other hand, research has shown that phenols and oxygenated terpenoids extracted from plants were the primary effective constituents exerting antimicrobial activity [9]. Trombetta et al. [10] have demonstrated that terpenoids could increase membrane permeability by perturbing the fatty acid composition of the bacterial cell membrane, leading to the leakage of cellular contents. Similarly, the antimicrobial activity of phenols also resulted in structural and functional damages of cell membranes [9].

Amaranthus spp. crude extract is a natural substance containing alkaloids (betacyanins and betaxanthin), polyphenols (flavonoids, steroids, catechuic acid, and tannins), terpenoids (cerasinone and norecasantalic acid) and saponins [11]. Amaranthus viridis, Amaranthus hybridus, Amaranthus spinosus, and Amaranthus caudatus have been demonstrated to have broad-spectrum anti-bacterial activity [12-14]. Amornrit and Santiyanont [14] reported that the leaves extract of Amaranthus tricolor showed promising antioxidant properties. In another study, it was found that Amaranthus tricolor has a higher phenolic content and antioxidant capacity than Amaranthus viridis [15]. Therefore, there is substantial evidence that Amaranthus tricolor crude extract (ATCE) has antimicrobial activity, however, few researchers have reported the antimicrobial activity of ATCE against $S$. aureus.

In this study, we aimed to evaluate the antimicrobial activity of ATCE against S. aureus, and to elucidate the possible mechanism of action by studying the changes in cell membrane potential, intracellular $\mathrm{pH}\left(\mathrm{pH}_{\mathrm{in}}\right)$, content of bacterial protein and DNA, and cell morphology after treatment with ATCE. Moreover, the antimicrobial application of ATCE in lean cooked meat against S. aureus was also assessed by investigating the growth of $S$. aureus, and the value of $\mathrm{pH}$ and color change of lean cooked meat were assessed during storage.

\section{Materials and Methods}

\subsection{Bacteria and Culture Conditions}

S. aureus ATCC 13,565 was obtained from American Type Culture Collection (ATCC, Manassas, VA, USA) and the six other $S$. aureus strains (KLDS-sa-1,2; KLDS-sa-3,4; KLDS-sa-5; KLDS-sa-6) were respectively isolated from fresh pork, raw milk, fresh beef, and fresh chicken in Harbin, China. 
All strains were stored in Luria-Bertani (LB) broth with $20 \%$ glycerol $(v / v)$ at $-80{ }^{\circ} \mathrm{C}$. The strains were cultured in LB broth medium at $37^{\circ} \mathrm{C}$ for $24 \mathrm{~h}$, and then streaked onto Baird-Parker agar base (BP) plates to be incubated at $37^{\circ} \mathrm{C}$ for $24 \mathrm{~h}$. Next, a loopful of each strain was selected and inoculated into LB broth at $37^{\circ} \mathrm{C}$ for $20 \mathrm{~h}$ to get the pure S. aureus cultures for experiment. All isolates were used to assess disk diffusion and minimum inhibitory concentration (MIC), whereas S. aureus ATCC 13565 was used to analyze the growth curve, the possible mechanism of action, and application.

\subsection{Preparation of Amaranthus tricolor Crude Extracts}

Amaranthus tricolor samples were obtained from a local market of Xiang Fang district, Harbin, Heilongiiang province in China in June 2018. The picked intact leaves of the plants were washed with tap water to remove dirt and aired at $25^{\circ} \mathrm{C}$ in the laboratory, then dried at $40^{\circ} \mathrm{C}$ and ground into powder using a mechanical grinder (Yongkang boou machinery co., Ltd., Zhejiang, China). Approximately $50 \mathrm{~g}$ of the powder was extracted in $1000 \mathrm{~mL}$ of $70 \%(v / v)$ ethanol at $40{ }^{\circ} \mathrm{C}$ for $2 \mathrm{~h}$. The extracting solution was centrifuged at $2000 \times g$ for $10 \mathrm{~min}$ (Shanghai Centrifuge Institute Co., Ltd., Shanghai, China) to remove dregs. The supernatant was concentrated in a rotary evaporator at $40{ }^{\circ} \mathrm{C}$ until ethanol was removed and then the concentrate was stored at $-80^{\circ} \mathrm{C}$ to freeze and lyophilize to yield the dried powder.

\subsection{Disk Diffusion Assay}

The antimicrobial activity of ATCE was investigated using the disk diffusion method [16]. One-hundred microliters of bacterial suspension (approximately $10^{6} \mathrm{CFU} / \mathrm{mL}$ ) was spread evenly on the solid Luria-Bertani broth containing 1\% agar. The filter paper disks with $8 \mathrm{~mm}$ diameter were placed on each plate and added to $200 \mu \mathrm{L}$ of ATCE $(320 \mathrm{mg} / \mathrm{mL})$. The plates were incubated at $37^{\circ} \mathrm{C}$ for $24 \mathrm{~h}$ and the test was performed with three replications. The negative control was same microliters of sterilized water. The diameter (in millimeters) of the inhibition zone (DIZ) in which the colonies did not grow was measured to visually assess the antimicrobial effect of ATCE.

\subsection{Determination of MIC}

The MIC of ATCE against $S$. aureus strains was determined using the agar dilution method recommended by a previous report [17]. The different concentrations of ATCE (10, 20, 40, 80, 160, 320 , and $640 \mathrm{mg} / \mathrm{mL}$ ) were thoroughly mixed with TSA (approximately $50{ }^{\circ} \mathrm{C}$ ) in sterile 24-well plates, and $0.1 \mathrm{mg} / \mathrm{mL}$ ampicillin was used as the positive control. After hardening, $2 \mu \mathrm{L}$ of tested S. aureus strain (about $10^{6} \mathrm{CFU} / \mathrm{mL}$ ) was transferred into the culture medium and allowed to dry. Then the 24-well plates were incubated at $37^{\circ} \mathrm{C}$ for $24 \mathrm{~h}$. The MIC of ATCE against S. aureus was considered as the lowest concentration at which the visible growth of $S$. aureus was inhibited completely.

\subsection{Growth Curve of S. aureus ATCC 13565}

The growth curves of S. aureus ATCC 13565 were tested according to the method described by Shi et al. [18]. S. aureus ATCC 13565 was grown in $\mathrm{LB}$ broth until an $\mathrm{OD}_{600 \mathrm{~nm}}$ value of 0.2 was detected for the bacterial suspension. Then, $125 \mu \mathrm{L}$ of the bacterial suspension was added to each well in 96-well microtiter plates. The ATCE was added to the cultures and the final concentrations were adjusted to 0 , $0.5,1,1.5$, and $2 \mathrm{MIC}$, respectively. After being further cultured at $37^{\circ} \mathrm{C}$, the cell growth was monitored using a multimode plate reader at $600 \mathrm{~nm}$ (Tecan, Infinite ${ }^{\mathrm{TM}} \mathrm{M} 200 \mathrm{PRO}$, Männedorf, Switzerland) at 2 $\mathrm{h}$ intervals.

\subsection{Measurement of Membrane Potential}

The membrane potential of $S$. aureus ATCC 13565 with different ATCE treatments was measured according to the previous reports by Fei et al. [19]. A membrane-potential-sensitive fluorescent probe, bis-(1,3-dibutylbarbituric acid) trimethine oxonol (DiBAC4(3); Beijing Solarbio Science and Technology 
Co. Ltd., Beijing, China) and $125 \mu \mathrm{L}$ of bacteria solution (approximately $10^{7} \mathrm{CFU} / \mathrm{mL}$ ) were added in a black and opaque 96-well plate (Corning Institute, New York City, New York State, USA) and incubated at $30^{\circ} \mathrm{C}$ for $30 \mathrm{~min}$. Then, S. aureus ATCC 13565 were treated with 0, 1, and $2 \mathrm{MIC}$ of ATCE that were added in the 96-well plate. The fluorescence intensity of each well was measured using a multifunctional microplate reader at $492 \mathrm{~nm}$ excitation wavelengths and $515 \mathrm{~nm}$ emission wavelengths. The result of membrane potential was displayed by the value of relative fluorescence units (RFUs) as an indicator of signal intensity.

\subsection{Determination of Intracellular $\mathrm{pH}\left(\mathrm{pH}_{\text {in }}\right)$}

The changes in S. aureus ATCC 13565 cells' intracellular $\mathrm{pH}\left(\mathrm{pH}_{\mathrm{in}}\right)$ were assayed according to previous study with slight modifications [18]. Approximately $10^{8} \mathrm{CFU} / \mathrm{mL}$ of S. aureus ATCC 13565 bacterial suspension were incubated at $37^{\circ} \mathrm{C}$ for $30 \mathrm{~min}$ in the presence of $1.0 \mu \mathrm{M}$ carboxyfluorescein diacetate succinimidyl ester (CFDA SE) dye that was used as the $\mathrm{pH}_{\text {in }}$ fluorescent probe. The cells were centrifuged at 11,200 $\times g$ for $5 \mathrm{~min}$ and resuspended in sterile normal saline (NS). The bacterial suspension was added in $10 \mathrm{mM}$ glucose solution and incubated for $30 \mathrm{~min}$ at $37^{\circ} \mathrm{C}$, followed by centrifuging at 11,200 $\times \mathrm{g}$ for $5 \mathrm{~min}$, washed twice and resuspended in NS. Equal volumes $(125 \mu \mathrm{L})$ of bacteria solution and 0,1, and 2 MIC of ATCE were added in a black and opaque 96-well plate. Fluorescence intensities were detected by a microplate reader after treatment for 20 min (Tecan, Infinite ${ }^{\mathrm{TM}}$ M200 PRO, Männedorf, Switzerland). The measurement system was set to excitation wavelengths of $440 \mathrm{~nm}$ and emission wavelengths of $490 \mathrm{~nm}$, and maintained at $25^{\circ} \mathrm{C}$. The $\mathrm{pH}_{\text {in }}$ was determined as the ratio of the fluorescence signal at the $\mathrm{pH}$-sensitive wavelength $(490 \mathrm{~nm})$ and that at the $\mathrm{pH}$-insensitive wavelength $(440 \mathrm{~nm})$. The ultimate fluorescences of samples were calculated by deducting the fluorescence of cell-free controls.

\subsection{Sodium Dodecyl Sulfate-Polyacrylamide Gel Electrophoresis (SDS-PAGE)}

The effect of ATCE on the bacterial protein of S. aureus ATCC 13565 was analyzed using SDS-PAGE according to Chen et al. [20]. Approximately $10^{7} \mathrm{CFU} / \mathrm{mL}$ of $S$. aureus ATCC 13,65 bacterial suspension was treated with 1 and 2 MIC of ATCE for 3, 6, 9, and $12 \mathrm{~h}$ at $37^{\circ} \mathrm{C}$ followed by withdrawal of bacterial suspensions and centrifugation $(8000 \times g)$ at $4{ }^{\circ} \mathrm{C}$ for $10 \mathrm{~min}$ to prepare the supernatants. Untreated S. aureus ATCC 13565 cells were analyzed with the same processing as a negative control. The mixture of supernatants $(10 \mu \mathrm{L})$ and SDS-PAGE loading buffer $(5 \mu \mathrm{L})$ was then heated at $95^{\circ} \mathrm{C}$ for $10 \mathrm{~min}$ and the bacterial proteins was separated by SDS-PAGE using a 5\% stacking gel and a $15 \%$ separating gel. Finally, the protein bands were stained with Coomassie brilliant blue R-250 (Beijing Solarbio Sciences and Technology Co. Ltd., Beijing, China). The images were taken with an HP scanner (HP 1000, Silicon Valley, California, USA).

\subsection{Agarose Gel Electrophoresis for DNA Fragmentation}

The DNA fragmentation of S. aureus ATCC 13565 was determined using agarose gel electrophoresis as mentioned in previous research [21]. Approximately $10^{8} \mathrm{CFU} / \mathrm{mL}$ of S. aureus ATCC 13565 cells was treated with 0,1 , and 2 MIC of ATCE at $37^{\circ} \mathrm{C}$ for 2, 4, and $10 \mathrm{~h}$. The genomic DNA was extracted according to the instructions of a bacterial genomic DNA extraction kit (Tiangen Biotech Co., Ltd., Beijing, China). The extracted DNA samples were electrophoresed using agarose gel (1.5\%) at $100 \mathrm{~V}$ for $30 \mathrm{~min}$ and the gels were stained for $15 \mathrm{~min}$ using $10 \mathrm{mg} / \mathrm{mL}$ of ethidium bromide. Finally, the gels were visualized by a gel imaging system (Bio-Rad, Hercules, California, USA).

\subsection{Transmission Electron Microscopy}

The cellular morphology of S. aureus ATCC 13565 cells with different ATCE treatments was observed using a transmission electron microscope (Hitachi, Tokyo, Japan) according to previous reports [17]. After treatments with 0, 1, and 2 MIC of ATCE for $4 \mathrm{~h}$, the working S. aureus ATCC 13565 cells were collected by centrifugation at $7000 \times g$ for $10 \mathrm{~min}$ and fixed in $0.1 \mathrm{M}$ sodium 
phosphate buffer containing $2.5 \%$ glutaraldehyde at $4{ }^{\circ} \mathrm{C}$ for $2 \mathrm{~h}$ and then washed three times with NS. After dehydrating with $50 \%, 70 \%, 90 \%$, and $100 \%$ ethanol for $10 \mathrm{~min}$, the cells were embedded in Epon Lx-112 (Ladd Research, Williston, North Carolina, USA). Then, the samples were cut into sections of 50 to $60 \mathrm{~nm}$ and stained using double staining with uranyl acetate and lead citrate. Finally, the cell morphology of samples was observed under the TEM.

\subsection{Application of ATCE in Cooked Meat and Microbiological Analysis}

Fresh lean pork was purchased from the local market and cut into cube blocks (approximately $2 \times$ $2 \times 2 \mathrm{~cm}^{3}$ ). Then the cube blocks were sterilization for $20 \mathrm{~min}$ at $121^{\circ} \mathrm{C}$ to obtain the sterile lean cooked pork samples. The sterile samples were treated with 0,1 , and 2 MIC of ATCE for 30 min, respectively. Approximately $10^{3} \mathrm{CFU} / \mathrm{mL}$ of $S$. aureus ATCC 13565 cells was inoculated into the samples treated with ATCE. The bacterial suspension was mixed with each sample for $15 \mathrm{~s}$ using a sterile applicator stick. Then, the inoculated samples were sealed and stored using aseptic bags at $4{ }^{\circ} \mathrm{C}$ for 6 days. On days 0 , 3 , and 6, the samples $(10 \mathrm{~g})$ were taken out in turn and mashed (Stomacher 400 Laboratory Blender, Seward, Worthington, UK) on medium power mode for $30 \mathrm{~s}$ in $0.1 \%$ sterile NS (90 mL). The suspension liquid samples were appropriately diluted by NS. Finally, the number of S. aureus ATCC 13565 on lean cooked pork was enumerated on Baird-Parker (BP, Difco Labs, Detroit, Michigan, USA) plates by spreading $100 \mu \mathrm{L}$ of the sample dilution.

\subsection{The $\mathrm{pH}$ Value Measurement}

The cooked pork samples were treated with 0,1 , and 2 MIC of ATCE for $30 \mathrm{~min}$ and then sealed and stored using aseptic bags at $4{ }^{\circ} \mathrm{C}$ for 6 days. On days 0,3 , and 6 , the treated samples $(10 \mathrm{~g})$ were homogenized in $90 \mathrm{~mL}$ distilled water using an Ultra Turrax T25 homogenizer (Janke and Kunkel, IKA-Labortechnik, GmbH and Co., Staufen, Germany). The $\mathrm{pH}$ of the samples was measured using a portable $\mathrm{pH}$ meter (Radiometer, Copenhagen, Denmark).

\subsection{Color Determination}

The pretreatment process for cooked pork samples was the same as for $\mathrm{pH}$ measurement in Section 2.12. The surface color of cooked pork samples was measured using a CR-300 Chroma Meter (Minolta Co., Osaka, Japan) with calibration using a white tile according to the CIE color space system [22]. The $L^{*}, a^{*}$, and $b^{*}$ values represent lightness, redness, and yellowness, respectively. In addition, the chroma value $\left(\mathrm{C}^{*}\right)$ and hue angle value $\left(\mathrm{h}^{*}\right)$ were generate according to the following formulas from previous study [23].

$$
\begin{gathered}
C^{*}=\left[\left(a^{* 2}+b^{* 2}\right)^{\frac{1}{2}}\right] \\
h^{*}=\left[\operatorname{arctangent}\left(\frac{b^{*}}{a^{*}}\right)\right]
\end{gathered}
$$

\subsection{Statistical Analysis}

The data obtained in this study were described by means and standard deviations. The date of the disk diffusion assay, membrane potentials, $\mathrm{pH}_{\text {in }}$ values, the bacterial survival counts, and the values of $\mathrm{pH}$ and color determination were analyzed using both analysis of variance (ANOVA) and Duncan's test. The two methods were used to determine the significance level and get a more rigorous data analysis. In addition, SPSS 22.0 software (SPSS Inc., Chicago, IL, USA) was used to conduct the ANOVA. Significant differences among the means $(p<0.05)$ was confirmed by Duncan's multiple range test. All experiments were carried out in triplicate. 


\section{Results}

\subsection{Antimicrobial Effects of ATCE on S. aureus}

The antimicrobial effect of ATCE against S. aureus was shown in Table 1. The DIZs of seven $S$. aureus strains ranged from $12.63 \pm 0.34$ to $12.94 \pm 0.43 \mathrm{~mm}$ in the presence of $320 \mathrm{mg} / \mathrm{mL}$ of ATCE and the DIZ values of ATCE against $S$. aureus strains showed no significant difference $(p>0.05)$. Bacterial colonies of seven $S$. aureus did not grow when treated with $80 \mathrm{mg} / \mathrm{mL}$ of ATCE. Therefore, the MIC of ATCE against seven S. aureus strains was determined to be $80 \mathrm{mg} / \mathrm{mL}$.

Table 1. Antimicrobial activity of Amaranthus tricolor crude extract (ATCE) against all six Staphylococcus aureus strains.

\begin{tabular}{ccc}
\hline Strain & DIZ $(\mathbf{m m})$ & MIC $(\mathbf{m g} / \mathbf{m L})$ \\
\hline ATCC 13565 & $12.82 \pm 0.50^{\mathrm{a}}$ & 80 \\
KLDS-sa-1 & $12.94 \pm 0.43^{\mathrm{a}}$ & 80 \\
KLDS-sa-2 & $12.71 \pm 0.85^{\mathrm{a}}$ & 80 \\
KLDS-sa-3 & $12.78 \pm 0.51^{\mathrm{a}}$ & 80 \\
KLDS-sa-4 & $12.86 \pm 0.72^{\mathrm{a}}$ & 80 \\
KLDS-sa-5 & $12.89 \pm 0.57^{\mathrm{a}}$ & 80 \\
KLDS-sa-6 & $12.63 \pm 0.34^{\mathrm{a}}$ & 80
\end{tabular}

${ }^{a}$ Column values with different lowercase letters are significantly different $(p<0.05)$. DIZ: diameter of the inhibition zone; MIC: minimum inhibitory concentration.

\subsection{Growth Curve of S. aureus ATCC 13565}

The antimicrobial activity of ATCE against S. aureus ATCC 13565 was evaluated by growth curve analysis, at different concentrations ranging from $0.5 \mathrm{MIC}$ to $2 \mathrm{MIC}$. The results indicated that effective inhibition of growth was achieved after $10 \mathrm{~h}$ by ATCE at 1, 1.5, and 2 MIC. In addition, ATCE at 0.5 MIC slightly inhibited S. aureus ATCC 13565 in comparison with the control (Figure 1).

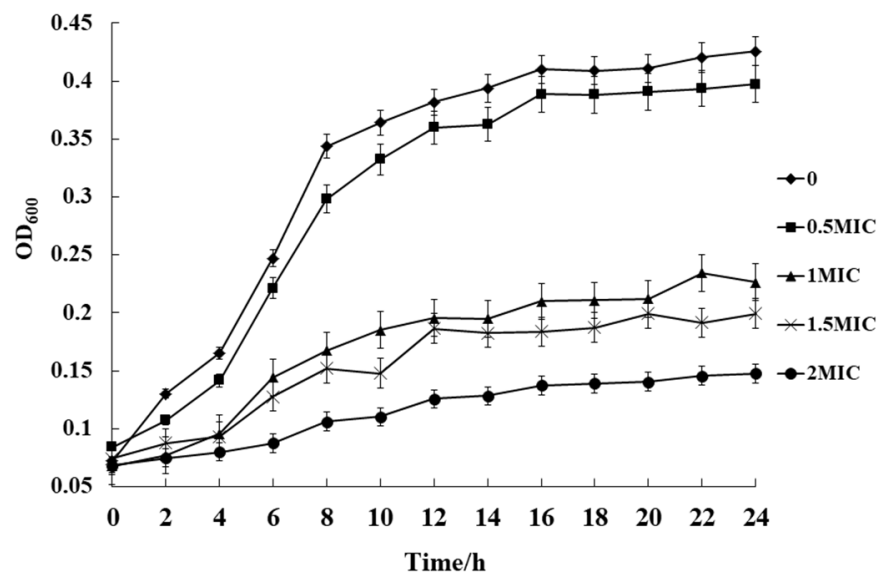

Figure 1. Growth curves of S. aureus ATCC 13565 cultured in Luria-Bertani (LB containing with 0, 0.5, $1,1.5$, and 2 MIC of ATCE. Error bars denote standard deviation $(n=3)$.

\subsection{Changes in Membrane Potential}

The changes of membrane potential can be reflected by observing the fluorescence intensity in cells, and the increase (decrease) of fluorescence intensity indicated cell membrane depolarization (hyperpolarization). As shown in Figure 2, compared with the untreated group, the fluorescence intensities of $S$. aureus ATCC 13565 cells treated with ATCE were significantly increased $(p<0.05)$. This indicates that ATCE can arouse depolarization in S. aureus ATCC 13565 cells. Moreover, the cells treated with 1 and 2 MIC of ATCE showed no difference in fluorescence intensity $(p>0.05)$. 


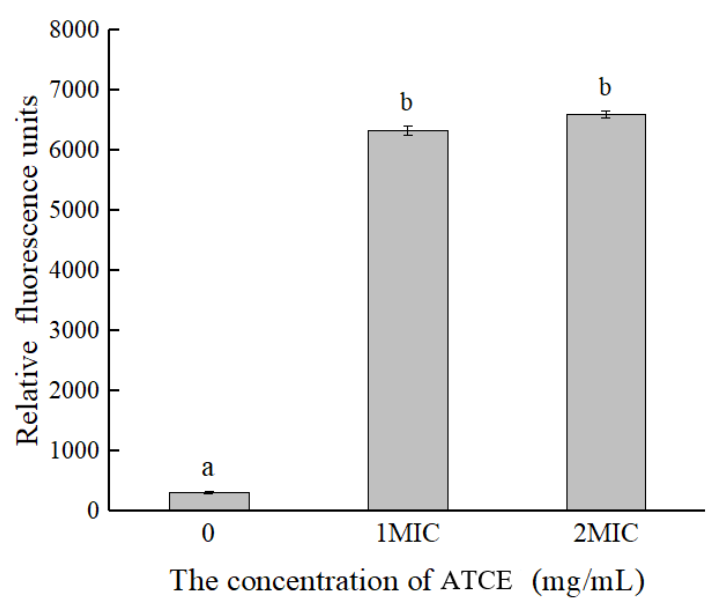

Figure 2. Differences in membrane potentials of $S$. aureus ATCC 13565 after treatment with ATCE at 0,1 , and 2 MIC. Values denote the means of triplicate measurements. Error bars represent standard deviation $(n=3)$. Different lowercase letters $(\mathrm{a}, \mathrm{b})$ represent significant differences $(p<0.05)$.

\subsection{Changes in $p H_{\text {in }}$}

A clear change in $\mathrm{pH}_{\text {in }}$ appeared after adding ATCE (Figure 3). After treatment with 1 MIC of ATCE, the values of $S$. aureus ATCC 13565 cell $\mathrm{pH}_{\text {in }}$ decreased from $8.02 \pm 0.77$ to $5.44 \pm 1.07$. In addition, the values of $S$. aureus ATCC 13565 cell $\mathrm{pH}_{\text {in }}$ decreased significantly $(p<0.05)$ from $8.02 \pm 0.77$ to $4.78 \pm 0.72$ at 2 MIC of ATCE, where the reduction was greater than that for 1 MIC of ATCE, but not significantly different $(p>0.05)$. This also suggests that ATCE is bactericidal to $S$. aureus ATCC 13565 when the concentration is greater than or equal to 2 MIC.

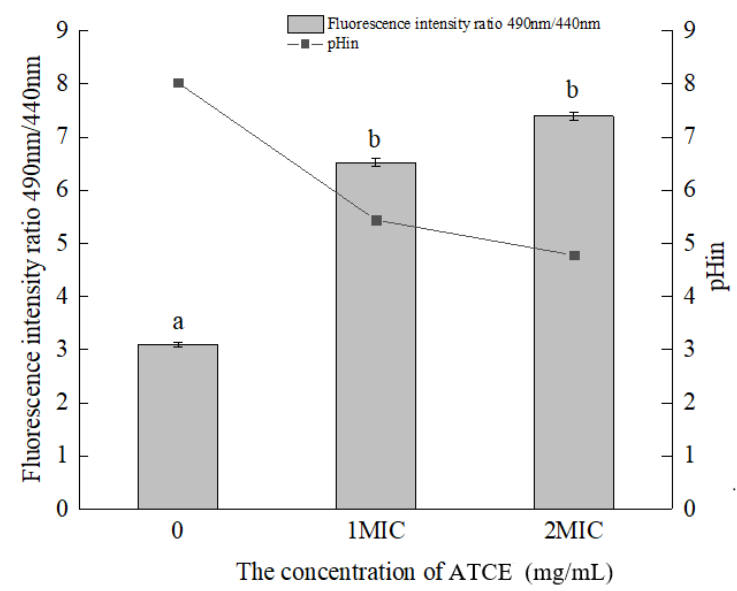

Figure 3. Differences in the intracellular $\mathrm{pH}$ (pHin) of S. aureus ATCC 13565 after treatment with ATCE at 0,1 , and 2 MIC. Values denote the means of triplicate measurements. Error bars represent standard deviation $(n=3)$. Different lowercase letters $(\mathrm{a}, \mathrm{b})$ represent significant differences $(p<0.05)$.

\subsection{SDS-PAGE Analysis}

The SDS-PAGE images indicate that the gel bands of S. aureus ATCC 13565 treated with 1 and 2 MIC of ATCE gradually faded as time went on (Figure 4). The protein bands became much weaker and disappeared after treatment with 2 MIC of ATCE for $12 \mathrm{~h}$, suggesting ATCE has a bactericidal effect on S. aureus ATCC 13565. As ATCE treatment concentration increased, the bands became weaker and the protein contents reduced. 


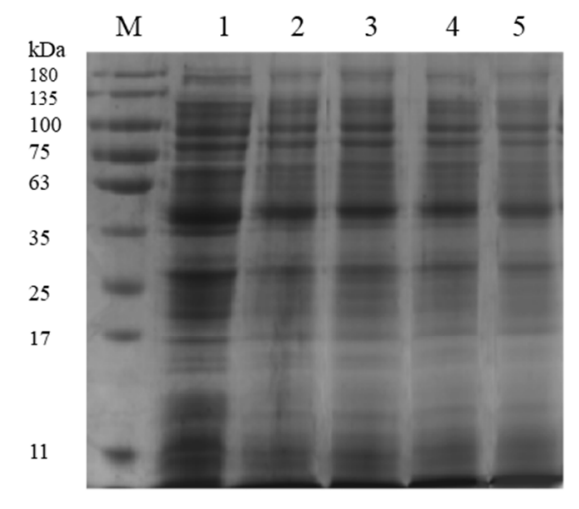

(A)

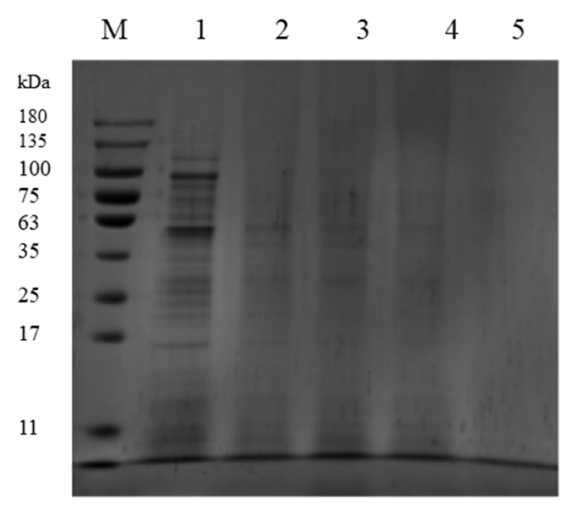

(B)

Figure 4. SDS-PAGE analysis of S. aureus ATCC 13565 proteins after treatment with ATCE at (A) 1 MIC and (B) 2 MIC. Lane M: marker. Lanes 1: control; Lanes 2, 3, 4, and 5: samples treated for 3, 6, 9, and 12 $\mathrm{h}$, respectively.

\subsection{DNA Cleavage Analysis}

The results of teh genomic DNA electrophoretogram of bacterial cells treated with ATCE are shown in Figure 5. The DNA bands of S. aureus ATCC 13565 after exposure to 1 and 2 MIC of ATCE became faint or even disappeared as the concentration of ATCE and time increased, compared to the untreated samples. The DNA bands disappeared when S. aureus ATCC 13565 was treated with 2 MIC of ATCE for $10 \mathrm{~h}$. This suggests that ATCE has bactericidal function on S. aureus ATCC 13565 when the concentration is greater than or equal to 2 MIC.

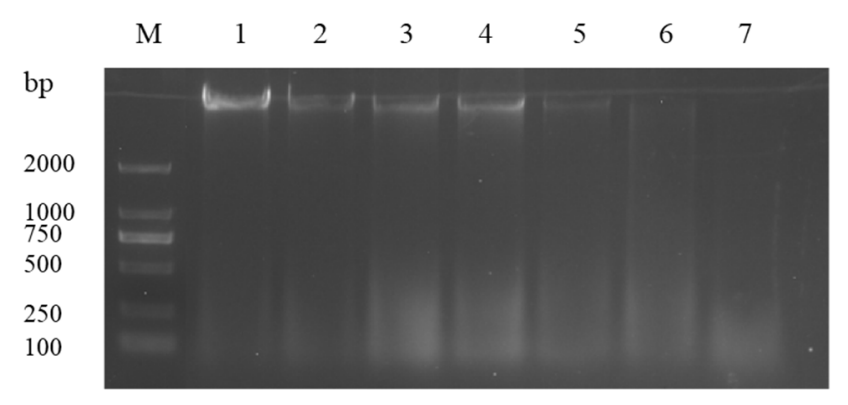

Figure 5. DNA cleavage activity of $S$. aureus ATCC 13565 strains after treating with ATCE at 1 MIC and 2 MIC. Lane M: marker. Lane 1: control group. Lanes 2, 3, and 4: treated with 1 MIC of ATCE for 2, 4, and 10 h, respectively. Lanes 5, 6, and 7: treated with 2 MIC of ATCE for 2, 4, and $10 \mathrm{~h}$, respectively.

\subsection{Transmission Electron Microscope Observation}

TEM was used to observe the cell morphology of S. aureus ATCC 13565 (Figure 6). Untreated cells of S. aureus ATCC 13565 maintained normal morphology and intact cell structure (Figure 6A). The cytoplasmic membrane was gradually separated from the cell wall and the intracellular components leaked after treatment with 1 MIC of ATCE (Figure 6B). Meanwhile, the degree of cell deformation and cytoplasmic leakage obviously increased when the S. aureus ATCC 13565 cells were treated with 2 MIC of ATCE (Figure 6C).

\subsection{Antimicrobial Effects of ATCE}

Amaranthus tricolor crude extract (ATCE) at 1 and 2 MIC slightly reduced the numbers of S. aureus ATCC 13565 in inoculated lean cooked pork in the first 3 days of storage compared to the initial populations (Figure 7), and there was no significant difference between the results of these two concentrations $(p>0.05)$. The numbers of $S$. aureus ATCC 13565 treated with 2 MIC was significantly lower than in the sample treated with 1 MIC after 6 days $(p<0.05)$. 


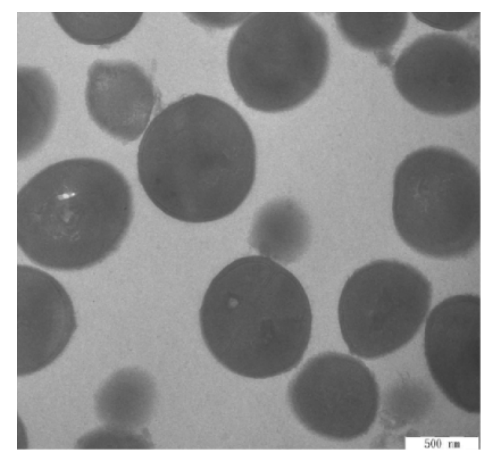

(A)

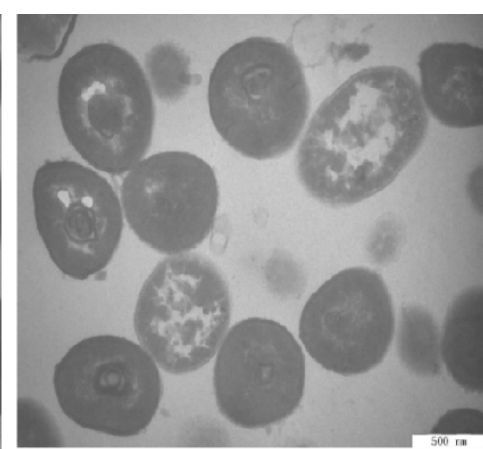

(B)

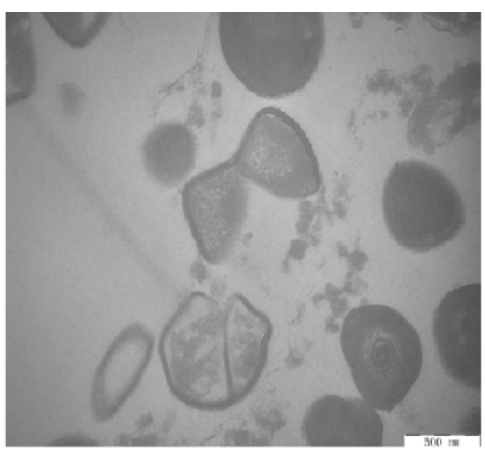

(C)

Figure 6. TEM images of $S$. aureus ATCC 13565 strains $(40,000 \times)($ A) untreated for $4 \mathrm{~h},(\mathbf{B})$ treated with 1 MIC of ATCE for $4 \mathrm{~h}$, and (C) treated with 2 MIC of ATCE for $4 \mathrm{~h}$.

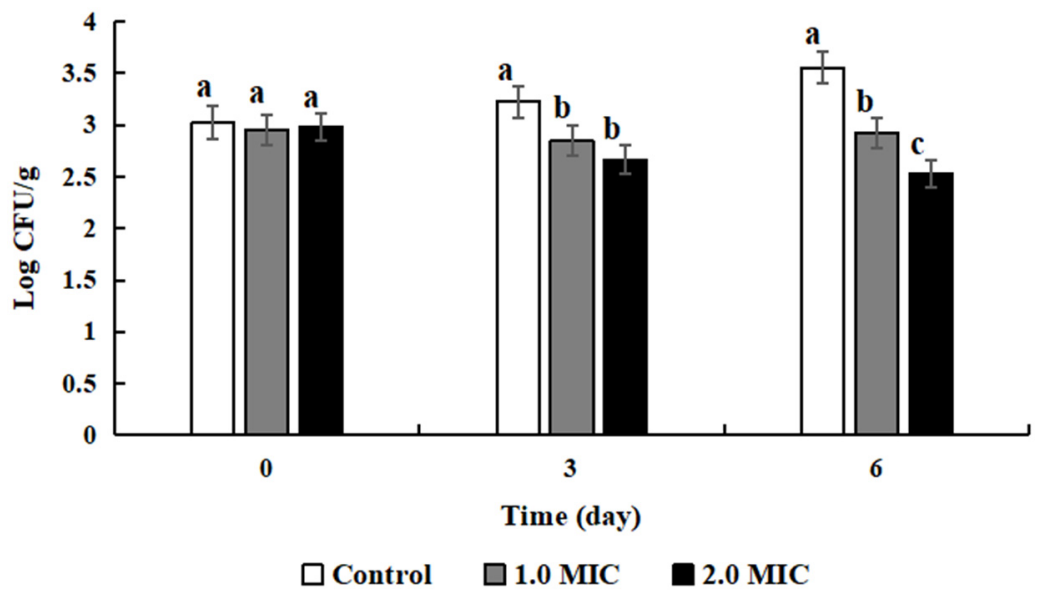

Figure 7. Antibacterial effect of ATCE on S. aureus ATCC 13565 inoculated into sterile lean cooked pork during storage. Values denote the means of triplicate measurements. Error bars represent standard deviation $(n=3)$. Different letters represent significant differences $(p<0.05)$.

\subsection{Effects of ATCE on $\mathrm{pH}$ Change}

The $\mathrm{pH}$ values of lean cooked pork over the 6 days of storage did not show significant changes at 1 and 2 MIC of ATCE $(p>0.05)$. However, after being treated with different concentrations of ATCE, the $\mathrm{pH}$ values of lean cooked pork treated with 1 and 2 MIC of ATCE were slightly decreased $(p<0.05)$ compared to the control during the same storage time (Table 2).

Table 2. The $\mathrm{pH}$ values of cooked pork with ATCE during storage for 6 days.

\begin{tabular}{cccc}
\hline \multirow{2}{*}{ Storage Time (Days) } & \multicolumn{3}{c}{ Treatments (Cooked Meat + Extract) } \\
\cline { 2 - 4 } & Control & 1 MIC & 2 MIC \\
\hline 0 & $6.04 \pm 0.02^{\mathrm{aA}}$ & $5.99 \pm 0.02^{\mathrm{bA}}$ & $5.89 \pm 0.01^{\mathrm{cA}}$ \\
3 & $6.05 \pm 0.02^{\mathrm{aA}}$ & $5.98 \pm 0.02^{\mathrm{bA}}$ & $5.90 \pm 0.01^{\mathrm{cA}}$ \\
6 & $6.05 \pm 0.02^{\mathrm{aA}}$ & $5.99 \pm 0.02^{\mathrm{bA}}$ & $5.88 \pm 0.02^{\mathrm{cA}}$ \\
\hline
\end{tabular}

All the values are the means of three replicated measurements \pm standard deviation (SD). Values with different superscript letters $(\mathrm{a}-\mathrm{c})$ within a row in a row are significantly different $(p<0.05)$. Values with the same superscript letters (A) within a row in a row are not significantly different $(p>0.05)$.

\subsection{Effects of ATCE on Color Change}

The effects of ATCE treatment on the color changes of lean cooked pork during storage are shown in Table 3. The $\mathrm{L}^{*}$ value of lean cooked pork was decreased by treatment with ATCE. The addition of ATCE increased the $\mathrm{a}^{*}$ value of the cooked pork as the extract concentration of ATCE increased $(p<0.05)$. 
The $b^{*}$ values of samples treated or not treated with ATCE displayed no significant differences during storage $(p>0.05)$. The $C^{*}$ values increased slightly as the storage time increased and significantly increased $(p<0.05)$ when the ATCE treatment concentration increased at same storage time. The $h^{*}$ value of cooked pork that was treated with the same ATCE concentration did not significantly change during storage. However, the $\mathrm{h}^{*}$ value declined as the concentration of ACTE increased and the number of storage days was the same.

Table 3. Color changes of the cooked pork treated with ATCE during storage.

\begin{tabular}{cccc}
\hline \multirow{2}{*}{ Storage Time (Days) } & \multicolumn{3}{c}{ Treatments (Cooked Meat + Extract) } \\
\cline { 2 - 4 } & Control & $\mathbf{1 ~ M I C}$ & $\mathbf{2 ~ M I C}$ \\
\hline L $^{*}$ value & - & - & - \\
0 & $63.70 \pm 0.16^{\mathrm{Aa}}$ & $48.66 \pm 0.11^{\mathrm{Bb}}$ & $42.11 \pm 0.34^{\mathrm{Ac}}$ \\
3 & $65.44 \pm 0.04^{\mathrm{Ca}}$ & $48.50 \pm 0.18^{\mathrm{Bb}}$ & $43.28 \pm 0.26^{\mathrm{Bc}}$ \\
6 & $63.99 \pm 0.06^{\mathrm{Ba}}$ & $47.71 \pm 0.20^{\mathrm{Ab}}$ & $42.61 \pm 0.27^{\mathrm{Ac}}$ \\
$\mathrm{a}^{*}$ value & - & - & - \\
0 & $3.83 \pm 0.08^{\mathrm{Aa}}$ & $11.48 \pm 0.28^{\mathrm{Ab}}$ & $14.37 \pm 0.25^{\mathrm{Ac}}$ \\
3 & $3.54 \pm 0.09^{\mathrm{Ba}}$ & $11.89 \pm 0.23^{\mathrm{Ab}}$ & $13.97 \pm 0.07^{\mathrm{Ac}}$ \\
6 & $3.14 \pm 0.06^{\mathrm{Ca}}$ & $11.76 \pm 0.37^{\mathrm{Ab}}$ & $13.91 \pm 0.34^{\mathrm{Ac}}$ \\
$\mathrm{b}^{*}$ value & - & - & - \\
0 & $16.71 \pm 0.06^{\mathrm{Aa}}$ & $16.15 \pm 0.23^{\mathrm{Ab}}$ & $16.28 \pm 0.08^{\mathrm{Ab}}$ \\
3 & $16.67 \pm 0.22^{\mathrm{Ba}}$ & $16.16 \pm 0.05^{\mathrm{Ab}}$ & $16.07 \pm 0.26^{\mathrm{Ab}}$ \\
6 & $17.37 \pm 0.20^{\mathrm{Aa}}$ & $16.52 \pm 0.12^{\mathrm{Bb}}$ & $16.01 \pm 0.10^{\mathrm{Ac}}$ \\
$\mathrm{C}^{*}$ value & - & - & - \\
0 & $17.14 \pm 0.07^{\mathrm{Aa}}$ & $20.11 \pm 0.15^{\mathrm{Ab}}$ & $21.71 \pm 0.14^{\mathrm{Ac}}$ \\
3 & $17.03 \pm 0.29^{\mathrm{Aa}}$ & $20.20 \pm 0.21^{\mathrm{Bb}}$ & $21.28 \pm 0.24^{\mathrm{Ac}}$ \\
6 & $17.65 \pm 0.25^{\mathrm{Ba}}$ & $20.27 \pm 0.24^{\mathrm{Bb}}$ & $21.21 \pm 0.17^{\mathrm{Bc}}$ \\
$\mathrm{h}^{*}$ value & - & - & - \\
0 & $1.34 \pm 0.01^{\mathrm{Aa}}$ & $0.95 \pm 0.02^{\mathrm{Ab}}$ & $0.83 \pm 0.01^{\mathrm{Ac}}$ \\
3 & $1.36 \pm 0.00^{\mathrm{Ba}}$ & $0.93 \pm 0.01^{\mathrm{Ab}}$ & $0.85 \pm 0.01^{\mathrm{Ac}}$ \\
6 & $1.39 \pm 0.00^{\mathrm{Ca}}$ & $0.95 \pm 0.02^{\mathrm{Ab}}$ & $0.85 \pm 0.02^{\mathrm{Ac}}$
\end{tabular}

All the values are the means of three replicated measurements \pm standard deviation (SD). Values with different superscript letters $(\mathrm{a}-\mathrm{c})$ within a row in a row are significantly different $(p<0.05)$. Values with different superscript letters $(\mathrm{A}-\mathrm{C})$ within a row in a row are significantly different $(p<0.05)$.

\section{Discussion}

Phytochemicals like alkaloids, polyphenols, terpenoids, and saponins have been established as the active constituents present in Amaranthus spp., and the plant extracts have been shown as effective against foodborne pathogens [11]. Some plants of Amaranthus spp. have also demonstrated general action against $S$. aureus strains. Bulbul et al. [12] and Tahir and Khan [13] found that the DIZ was 14.5 and $13.80 \mathrm{~mm}$, respectively, when strains of S. aureus were treated with $n$-hexane extracts of Amaranthus spinosus and Amaranthus viridis. Maiyo et al. [24] reported antimicrobial effects of Amaranthus caudatus against $S$. aureus strains, with an MIC of $155.6 \mathrm{mg} / \mathrm{mL}$. In addition, some polyphenol extracts such as oregano extracts (including thymol, carvacrol, and eugenol) and olive oil polyphenol extract have been determined to possess antimicrobial activity against S. aureus with MICs of $10 \mathrm{mg} / \mathrm{mL}$ and $1.25 \mathrm{mg} / \mathrm{mL}$, respectively [7,8]. In this study, the DIZ and MIC of ATCE against S. aureus ATCC 13565 strains were $12.82 \pm 0.50 \mathrm{~mm}$ and $80 \mathrm{mg} / \mathrm{mL}$, which indicated that antimicrobial activity of ATCE was effective. The growth curve showed that ATCE inhibited the growth of S. aureus ATCC 13565, and the lag phase and specific growth rate in the exponential phase became longer and lower with the increase of ATCE concentrations, which was similar with the growth of Cronobacter sakazakii treated with citral [18]. This result indicated that the antimicrobial activity of ATCE was worth confirming.

It is essential for life of the all bacteria to maintain a membrane potential, which is used for producing energy, driving active transport of molecules across the membrane, empowering motility (flagella), and preventing the cytoplasm from equilibrating with the environment [25]. Membrane 
changes (depolarization and hyperpolarization) have been suggested to be one of the primary indicators of injured bacteria [17]. In this study, the results showed that S. aureus ATCC 13565 displayed cell membrane depolarization after treatment with ATCE, which occurs primarily due to the release of $\mathrm{K}^{+}$or $\mathrm{K}^{+}$with several other ions [18,25]. Similar results were also reported in the cells of Listeria monocytogenes exposed to olive oil polyphenol extract and Cronobacter sakazakii treated with citral $[18,21]$. In addition, the occurence of cell membrane hyperpolarization was associated with change in $\mathrm{pH}$ and leakage of $\mathrm{K}^{+}$[26].

Maintenance of $\mathrm{pH}_{\text {in }}$ homeostasis is considered to be critical to keep the correct DNA transcription and protein synthesis of the bacteria cell [27]. Cells with an intact membrane can maintain their internal $\mathrm{pH}$ through ion channels and pumps when the outside $\mathrm{pH}$ undergoes gentle change [18]. In this study, ATCE induced a decrease in the $\mathrm{pH}_{\text {in }}$ of $S$. aureus ATCC 13565 strains, indicating that membrane damage occurred. Similarly, Lambert et al. [28] demonstrated that thymol and carvacrol reduced the $\mathrm{pH}_{\mathrm{in}}$ of $\mathrm{S}$. aureus. Shi et al. [29] found that reductions of the internal $\mathrm{pH}$ of $C$. sakazakii strains were detected after treatments with lipoic acid. Therefore, the damage of cell membrane integrity led to the reduction of $\mathrm{pH}_{\mathrm{in}}$, which is considered as one of the important antimicrobial pathways of natural substances.

As the basic substance of life, protein plays an important part in the activity and physiological function of bacterial cells [19]. The contents of protein in S. aureus ATCC 13565 cells was decreased with treatment of antimicrobial agents, such as sugarcane bagasse extract and sugar beet molasses polyphenols $[20,28]$. In this study, the SDS-PAGE results also confirmed this. These results proved that natural extracts maybe have interacted with protein, increased the membrane permeability, and disturbed the synthesis of bacterial proteins. The membrane structure of the cell was destroyed by ATCE, resulting in the leakage of intracellular soluble contents. Therefore, the contents of bacterial protein reduced and the protein bands became weaker or not apparent as the treatment concentration of ATCE increased.

DNA carrying genetic information is in charge of bacterial growth, development, and inheritance [30]. After a treatment with ATCE, the bacterial DNA bands became fainter or even disappeared, resulting in DNA fragmentation. Moreover, this destructive effect was related to the concentration of ATCE, which was in step with the results in previous studies that cajanol inhibits the growth of $S$. aureus by DNA cleavage [31]. It can be supposed that the possible mechanism of action is that ATCE destroys the bacterial cell membrane and increases its permeability, resulting in the leakage of DNA or promoting the entrance of ATCE in bacterial cells and interaction with DNA, disturbing gene expression and thereby causing bacterial cell death.

TEM observation is powerful tool to better observe the cell morphology of natural products' action on bacterial cells [17]. After treatment with ATCE, the cell morphology of S. aureus ATCC 13565 was obviously seriously damaged and there was cytoplasmic leakage as the cell membrane permeability increased, breaking the cell homeostasis. Similar results have been found that sugar beet molasses polyphenols and sugarcane bagasse extract caused $S$. aureus cell deformation and cytoplasmic leakage $[20,28]$. Therefore, the visualization of membrane damage under TEM confirmed the increase of cell membrane permeability and the destruction of membrane structures by natural extracts, leading to cell membrane depolarization, decreases in $\mathrm{pH}_{\text {in, }}$ leakage of cytoplasm, bacterial protein reduction and DNA cleavage. The results demonstrated a valid antimicrobial effect against $S$. aureus strains.

Cooked meat products are generally regarded as safe, but can be contaminated by foodborne pathogens such as S. aureus during production, manufacturing, distribution, and preparation [31,32]. More importantly, cooked meat if contaminated by foodborne pathogens not only has spoiled flavor, aroma, taste, nutritional value, and overall quality, but also threatens human health and leads to illness and death [8]. In this study, ATCE could inhibit the growth of S. aureus and was found to injure cell membranes and depolarize bacteria cells, reduce $\mathrm{pH}_{\mathrm{in}}$, and change cell morphology, as well as reduce the bacterial protein content and cleave DNA to prevent the growth of S. aureus. Thus, ATCE possesses the potential to become a food additive due to its antimicrobial activities and can be used to improve 
the shelf-life and the safety of cooked meat. In addition, the ATCE action was proved by decreasing the numbers of $S$. aureus ATCC 13565 in inoculated lean cooked pork in this study. A similar study indicated that the grape seed extract inhibited the growth of E. coli O157:H7 and Salmonella typhimurium in cooked beef [22], showing that the natural extracts effectively inhibited microbial growth.

Natural antimicrobial systems could improve the stability and safety of cooked meats, and could also be influenced by many factors, such as the food components, $\mathrm{pH}$, as well as storage temperature [33]. Some studies have reported that the $\mathrm{pH}$ of cooked pork treated by plant extracts was within the range of 5.92-6.07 and concluded that the $\mathrm{pH}$ of the pork was unaffected by the addition of the extracts $[5,33]$. This phenomenon was consistent with the results of this study, where the $\mathrm{pH}$ values of lean cooked pork treated with different ATCE concentrations was decreased during the same storage time, but there were no significant changes with increased storage time. In brief, the ATCE had little influence on the $\mathrm{pH}$ value of lean cooked pork.

The color and color uniformity of cooked meats are the crucial conditions for consumer acceptance. The meat color can be simply reflected by lightness $\left(\mathrm{L}^{*}\right)$ and redness $\left(\mathrm{a}^{*}\right)$, but the yellowness $\left(\mathrm{b}^{*}\right)$ is not typically or intuitively related to meat [34]. The $C^{*}$ value indicates the hue intensity of the product, and larger values represent a greater saturation of the principle hue [35]. The $\mathrm{h}^{*}$ value indicates color changes during shelf life and larger values indicate less redness and a more well-done cooked color [35]. ATCE increased the $L^{*}$ and $a^{*}$ values of the lean cooked pork as the concentration increased. The slight increase of $\mathrm{L}^{*}$ values and the pronounced increase of $\mathrm{a}^{*}$ values of lean cooked pork was possibly due to the red-brown colour of the ATCE extract. Ifesan et al. [5] found that the addition of the Eleutherine americana crude extract led to an increase in the redness values of the pork but did not change the $L^{*}$ values. Moreover, the color $\left(\mathrm{L}^{*}\right.$ and $\left.\mathrm{a}^{*}\right)$ change of lean cooked pork treated with ATCE may result from the antioxidative effects of natural substances (e.g., alkaloids, polyphenols, and terpenoids). The increased $C^{*}$ value of cooked pork treated with ATCE showed the saturation enhancement of the principle hue. The decreased $\mathrm{h}^{*}$ value indicated a greater redness of the cooked meat. The results all demonstrate that ATCE was beneficial to the color of lean cooked pork. Color is an important visual cue, and an attractive food color can improve consumer acceptance of food and increase the desire to consume [36].

\section{Conclusions}

This study indicates that ATCE possesses antimicrobial activity against $S$. aureus and suggests that ATCE has a bactericidal function against $S$. aureus ATCC 13565 when the concentration is greater than or equal to 2 MIC. The antimicrobial action was associated with cell membrane depolarization, decrease of $\mathrm{pH}_{\mathrm{in}}$, bacterial protein reduction, DNA cleavage, and changed cell morphology. Moreover, its application to cooked pork preservation manifested as decreased numbers of $S$. aureus ATCC 13565 in inoculated lean cooked pork. The $\mathrm{pH}$ values of lean cooked pork treated with ATCE did not show significant changes as the storage time increased and saw a slight decrease during the same time period as the concentration was increased. The color of lean cooked pork treated with ATCE showed decreased $L^{*}$ values, increased $a^{*}$ values, no significant changes to $b^{*}$ values, increased $C^{*}$ values, and decreased $\mathrm{h}^{*}$ values during storage. These findings indicate that ATCE has the potential ability to control the growth of S. aureus in the food industry. However, ATCE dosage optimization, possible interactions between food components and natural extracts, and security problems need to be researched in the future.

Author Contributions: Conceptualization, L.G., K.D., P.F., and J.H.; Data curation, L.G., Y.W., X.B., Q.S., X.Y., Y.Z., and P.F.; Formal analysis, L.G. and P.F.; Resources, L.G. and J.H.; Writing-original draft, Y.W., X.B., and P.F.; Writing-review and editing, L.G., Y.W., X.B., K.D., Q.S., X.Y., Y.Z., P.F., and J.H. All authors have read and agreed to the published version of the manuscript.

Funding: This research was supported by the open fund of the key laboratory of dairy science of the ministry of education at Northeast Agricultural University (KLDS-18-007) and the special projects of central government to guide parochial science and technology development (107/83004700). 
Acknowledgments: The authors thank the anonymous reviewers and editors for their valuable advice.

Conflicts of Interest: The authors declare no conflicts of interest.

\section{References}

1. Safarpoor Dehkordi, F.; Basti, A.A.; Gandomi, H.; Misaghi, A.; Rahimi, E. Pathogenic Staphylococcus aureus in hospital food samples; prevalence and antimicrobial resistance properties. J. Food Saf. 2018, 38, e12501. [CrossRef]

2. Ma, Y.; Zhao, Y.; Tang, J.; Tang, C.; Chen, J.; Liu, J. Antimicrobial susceptibility and presence of resistance \& enterotoxins/enterotoxin-likes genes in Staphylococcus aureus from food. CyTA-J. Food 2018, 16, 76-84.

3. Kadariya, J.; Smith, T.C.; Thapaliya, D. Staphylococcus aureus and Staphylococcal Food-Borne Disease: An Ongoing Challenge in Public Health. Biomed Res. Int. 2014, 2014, 827965. [CrossRef] [PubMed]

4. Valero, A.; Pérez-Rodríguez, F.; Carrasco, E.; Fuentes-Alventosa, J.M.; García-Gimeno, R.M.; Zurera, G. Modelling the growth boundaries of Staphylococcus aureus: Effect of temperature, $\mathrm{pH}$ and water activity. Int. J. Food Microbiol. 2009, 133, 186-194. [CrossRef] [PubMed]

5. Ifesan, B.O.T.; Siripongvutikorn, S.; Hutadilok-Towatana, N.; Voravuthikunchai, S.P. Evaluation of the ability of eleutherine americana crude extract as natural food additive in cooked pork. J. Food Sci. 2009, 74, 352-357. [CrossRef] [PubMed]

6. Gyawali, R.; Ibrahim, S.A. Natural products as antimicrobial agents. Food Control 2014, 46, 412-429. [CrossRef]

7. Guo, L.; Gong, S.; Wang, Y.; Sun, Q.; Duo, K.; Fei, P. Antibacterial activity of olive oil polyphenol extract against Salmonella Typhimurium and Staphylococcus aureus. Foodborne Pathog. Dis. 2019, in press. [CrossRef]

8. Pesavento, G.; Calonico, C.; Bilia, A.R.; Barnabei, M.; Calesini, F.; Addona, R.; Mencarelli, L.; Carmagnini, L.; Di Martino, M.C.; Lo Nostro, A. Antibacterial activity of oregano, rosmarinus and thymus essential oils against Staphylococcus aureus and Listeria monocytogenes in beef meatballs. Food Control 2015, 54, 188-199. [CrossRef]

9. Rao, J.; Chen, B.; McClements, D.J. Improving the efficacy of essential oils as antimicrobials in foods: Mechanisms of action. Annu. Rev. Food Sci. Technol. 2019, 10, 365-387. [CrossRef]

10. Trombetta, D.; Castelli, F.; Sarpietro, M.G.; Venuti, V.; Cristani, M.; Daniele, C.; Saija, A.; Mazzanti, G.; Bisignano, G. Mechanisms of antibacterial action of three monoterpenes. Antimicrob. Agents Chemother. 2005, 49, 2474-2478. [CrossRef]

11. Peter, K.; Gandhi, P. Rediscovering the therapeutic potential of Amaranthus species: A review. Egypt. J. Basic Appl. Sci. 2017, 4, 196-205. [CrossRef]

12. Bulbul, I.J.; Nahar, L.; Ripa, F.A.; Haque, O. Antibacterial, cytotoxic and antioxidant activity of chloroform, n-hexane and ethyl acetate extract of plant amaranthus spinosus. Int. J. PharmTech Res. 2011, 3, 1675-1680.

13. Tahir, M.; Khan, J. Antimicrobial and irritant activities of the extracts of Malva parviflora L., Malvastrum coromandelianum L. and Amaranthus viridis L- A preliminary investigation. Pak. J. Pharm. 2010, 23, 2007-2010.

14. Amornrit, W.; Santiyanont, R. Neuroprotective effect of Amaranthus lividus and Amaranthus tricolor and their effects on gene expression of RAGE during oxidative stress in SH-SY5Y cells. Genet. Mol. Res. 2016, 15, 15027562. [CrossRef] [PubMed]

15. Routray, R.; Kar, M.; Sahu, R.K. Evaluation of antioxidant potential in selected leafy vegetables of Odisha, India. Int. J. Pharm. Pharm. Sci. 2013, 5, 232-235.

16. Zhang, Y.; Wu, Y.T.; Zheng, W.; Han, X.X.; Jiang, Y.H.; Hu, P.L.; Tang, Z.X.; Shi, L.E. The antibacterial activity and antibacterial mechanism of a polysaccharide from Cordyceps cicadae. J. Funct. Foods 2017, 38, 273-279. [CrossRef]

17. Fei, P.; Ali, M.A.; Gong, S.; Sun, Q.; Bi, X.; Liu, S.; Guo, L. Antimicrobial activity and mechanism of action of olive oil polyphenols extract against Cronobacter sakazakii. Food Control 2018, 94, 289-294. [CrossRef]

18. Shi, C.; Song, K.; Zhang, X.; Sun, Y.; Sui, Y.; Chen, Y.; Jia, Z.; Sun, H.; Sun, Z.; Xia, X.X. Antimicrobial activity and possible mechanism of action of citral against cronobacter sakazakii. PLoS ONE 2016, 11, e0159006. [CrossRef]

19. Fei, P.; Xu, Y.; Zhao, S.; Gong, S.; Guo, L. Olive oil polyphenol extract inhibits vegetative cells of Bacillus cereus isolated from raw milk. J. Dairy Sci. 2019, 102, 3894-3902. [CrossRef] 
20. Chen, M.; Zhao, Z.; Meng, H.; Yu, S. The antibiotic activity and mechanisms of sugar beet (Beta vulgaris) molasses polyphenols against selected food-borne pathogens. LWT-Food Sci. Technol. 2017, 82, 354-360. [CrossRef]

21. Guo, L.; Sun, Q.; Gong, S.; Bi, X.; Jiang, W.; Xue, W.; Fei, P. Antimicrobial activity and action approach of the olive oil polyphenol extract against Listeria monocytogenes. Front. Microbiol. 2019, 10, 1586. [CrossRef] [PubMed]

22. Ahn, J.; Grün, I.U.; Mustapha, A. Effects of plant extracts on microbial growth, color change, and lipid oxidation in cooked beef. Food Microbiol. 2007, 24, 7-14. [CrossRef] [PubMed]

23. Gagaoua, M.; Picard, B.; Monteils, V. Associations among animal, carcass, muscle characteristics, and fresh meat color traits in Charolais cattle. Meat Sci. 2018, 140, 145-156. [CrossRef] [PubMed]

24. Maiyo, Z.C.; Ngure, R.M.; Matasyoh, J.C.; Chepkorir, R. Phytochemical constituents and antimicrobial activity of leaf extracts of three Amaranthus plant species. Afr. J. Biotechnol. 2010, 9, 3178-3182.

25. Hammes, F.; Berney, M.; Egli, T. Cultivation-independent assessment of bacterial viability. Adv. Biochem. Eng. Biotechnol. 2011, 124, 123-150.

26. Bot, C.; Prodan, C. Probing the membrane potential of living cells by dielectric spectroscopy. Eur. Biophys. J. 2009, 38, 1049-1059. [CrossRef]

27. Bracey, D.; Holyoak, C.D.; Nebe-Von Caron, G.; Coote, P.J. Determination of the intracellular pH (pH(i)) of growing cells of Saccharomyces cerevisiae: The effect of reduced-expression of the membrane H+-ATPase. J. Microbiol. Methods 1998, 31, 113-125. [CrossRef]

28. Lambert, R.J.W.; Skandamis, P.N.; Coote, P.J.; Nychas, G.J.E. A study of the minimum inhibitory concentration and mode of action of oregano essential oil, thymol and carvacrol. J. Appl. Microbiol. 2001, 91, 453-462. [CrossRef]

29. Shi, C.; Sun, Y.; Zhang, X.; Zheng, Z.; Yang, M.; Ben, H.; Song, K.; Cao, Y.; Chen, Y.; Liu, X.; et al. Antimicrobial effect of lipoic acid against Cronobacter sakazakii. Food Control 2016, 59, 352-358. [CrossRef]

30. Cui, H.; Zhang, C.; Li, C.; Lin, L. Antimicrobial mechanism of clove oil on Listeria monocytogenes. Food Control 2018, 94, 140-146. [CrossRef]

31. Liu, X.L.; Zhang, X.J.; Fu, Y.J.; Zu, Y.G.; Wu, N.; Liang, L.; Efferth, T. Cajanol inhibits the growth of escherichia coli and Staphylococcus aureus by acting on membrane and DNA damage. Planta Med. 2011, 77, 158-163. [CrossRef] [PubMed]

32. Ghabraie, M.; Vu, K.D.; Tata, L.; Salmieri, S.; Lacroix, M. Antimicrobial effect of essential oils in combinations against five bacteria and their effect on sensorial quality of ground meat. LWT-Food Sci. Technol. 2016, 66, 332-339. [CrossRef]

33. Ahn, J.; Grün, I.U.; Mustapha, A. Antimicrobial and antioxidant activities of natural extracts in vitro and in ground Beef. J. Food Prot. 2004, 67, 148-155. [CrossRef] [PubMed]

34. Mancini, R.A.; Hunt, M.C. Current research in meat color. Meat Sci. 2005, 71, 100-121. [CrossRef] [PubMed]

35. Hunt, M.C.; King, A.; Barbut, S.; Clause, J.; Cornforth, D.; Hanson, D.; Lindahl, G.; Mancini, R.; Milkowski, A.; Mohan, A. AMSA Meat Color Measurement Guidelines; American Meat Science Association: Champaign, IL, USA, 2012; Volume 61820, ISBN 8005172672.

36. Carpenter, R.; O'Grady, M.N.; O'Callaghan, Y.C.; O’Brien, N.M.; Kerry, J.P. Evaluation of the antioxidant potential of grape seed and bearberry extracts in raw and cooked pork. Meat Sci. 2007, 76, 604-610. [CrossRef]

(C) 2020 by the authors. Licensee MDPI, Basel, Switzerland. This article is an open access article distributed under the terms and conditions of the Creative Commons Attribution (CC BY) license (http://creativecommons.org/licenses/by/4.0/). 